\title{
Performance analysis of photovoltaic systems: research at IDR/UPM Institute
}

\author{
Elena Roibás-Millán \\ Instituto de Microgravedad "Ignacio Da \\ Riva” (IDR/UPM) \\ Escuela Técnica Superior de Ingeniería \\ Aeronáutica y del Espacio (ETSIAE), \\ Universidad Politécnica de Madrid \\ Madrid, Spain \\ elena.roibas@upm.es \\ José Miguel Álvarez \\ Instituto de Microgravedad "Ignacio Da \\ Riva" (IDR/UPM) \\ Escuela Técnica Superior de Ingeniería \\ Aeronáutica y del Espacio (ETSIAE), \\ Universidad Politécnica de Madrid \\ Madrid, Spain \\ jm.alvarez@upm.es
}

\author{
Daniel Alfonso-Corcuera \\ Instituto de Microgravedad "Ignacio Da \\ Riva” (IDR/UPM) \\ Escuela Técnica Superior de Ingeniería \\ Aeronáutica y del Espacio (ETSIAE), \\ Universidad Politécnica de Madrid \\ Madrid, Spain \\ daniel.alfonso.corcuera@alumnos.upm.es
}

Santiago Pindado

Instituto de Microgravedad "Ignacio Da Riva” (IDR/UPM)

Escuela Técnica Superior de Ingeniería Aeronáutica y del Espacio (ETSIAE), Universidad Politécnica de Madrid Madrid, Spain santiago.pindado@upm.es

\author{
Javier Cubas \\ Instituto de Microgravedad "Ignacio Da \\ Riva” (IDR/UPM) \\ Escuela Técnica Superior de Ingeniería \\ Aeronáutica y del Espacio (ETSIAE), \\ Universidad Politécnica de Madrid \\ Madrid, Spain \\ j.cubas@upm.es
}

\author{
Alejandro M. Gomez-San-Juan \\ Instituto de Microgravedad "Ignacio Da \\ Riva" (IDR/UPM) \\ Escuela Técnica Superior de Ingeniería \\ Aeronáutica y del Espacio (ETSIAE), \\ Universidad Politécnica de Madrid \\ Madrid, Spain \\ alejandro.gomez@upm.es
}

\begin{abstract}
In this paper the work carried out at the IDR/UPM Institute on photovoltaic devices' performance is outlined. The aim of the work is to demonstrate the possibilities of the mathematical procedures developed beyond the space applications, in order to show them to other industrial sectors. The work carried out at the IDR/UPM Institute have been driven by selecting simple tools and procedures to model the solar cells/panels behavior, as modeling these photovoltaic devices is normally carried out by 1-Diode/2-Resistor equivalent circuit models, which might represent a unaffordable mathematical challenge for many professionals and technicians from the renewable energy sector.
\end{abstract}

Keywords-solar cell, solar panel, photovoltaic device, performance, I-V curve

\section{INTRODUCTION}

The UPMSat-2 project (see Fig.1), initiated in 2008 but officially started in 2011, has brought many research lines to Instituto Universitario de Microgravedad "Ignacio Da Riva" (IDR/UPM) from Universidad Politécnica de Madrid (UPM). Among these research lines it is possible to point out:

- Attitude Determination and Control Subsystems (ADCS's). The work of the IDR/UPM researchers has been driven towards control subsystems based on interaction with the Earth's magnetic field [1], [2].

- Thermal control subsystems. Mainly based on ESATAN analysis [3]-[5].

- Structural analysis of spacecraft and space instruments/systems [6]-[9].

- Spacecraft power subsystems. Devoted to photovoltaic systems (solar cells/panels) performance, harness design, and Li-ion batteries [10]-[20].

Besides, it should be also mentioned the impact of this project on the academic work carried out at the Aeronautics and Aerospace Engineering School (ETSIAE) from UPM.
More precisely, apart from several Ph.D. thesis and dissertations, this project has represented the perfect framework to teach space systems engineering with a Project Based Learning (PBL) methodology [19], [21], [22].

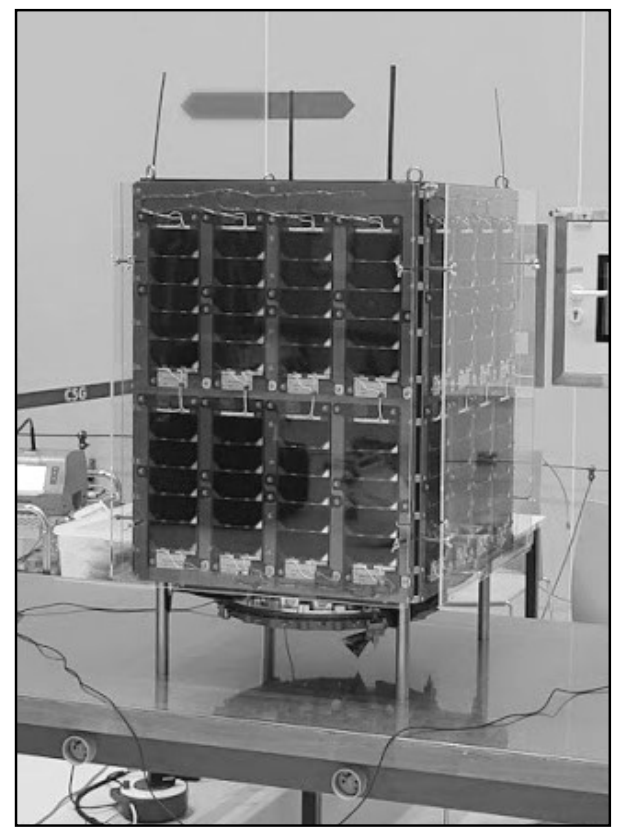

Fig. 1 Integration of the UPMSat-2 satellite at the Centre Spatial Guyanais of CNES (Kourou, French Guiana). February 2020.

Going back to the research line on spacecraft power subsystems, the work carried out in relation to solar cells/panels has been driven by a specific motivation, the use of analytical procedures to generate quick solutions in order accelerate early systems design. At IDR/UPM Institute, these analytical procedures have been implemented in the Concurrent Design Facility (CDF) for spacecraft mission design [23], [24], and in thermo-electric coupled analysis of satellite power subsystems with ESATAN. 
Additionally, it should be also pointed out that a simple procedure for solar panel testing was developed to check the performance of the UPMSat-2 solar panels. Within this simple procedure, the solar panels are tested under the sun, the results being extrapolated to the common Standard Test Conditions (STC) for space photovoltaic systems (AM0 and $\left.28^{\circ} \mathrm{C}\right)$ [17].

The aim of the present paper is to review the analytical and simple techniques related to photovoltaic systems performance analysis developed at the IDR/UPM Institute. The real possibility of using these techniques and procedures in other industrial sectors which deal with photovoltaic systems such as the renewable energy sector, or the construction sector, has driven us to write this work.

The present paper is organized as follows. In Section II, the main problem of modeling a solar cell/panel by using an equivalent circuit model is presented, whereas in Section III two analytical solutions defined at the IDR/UPM Institute are described. A simple and much simpler explicit methodology, equivalent to the analytical solutions described in Section III, is included in Section IV. Finally, conclusions are summarized in Section V. Additionally, an Appendix related to the Lambert function has been added in Section VI, as this function provides a very useful tool to solve explicit equations.

\section{SOLAR CELL/PANEL EQUIVALEN CIRCUIT MODEL}

There are several possibilities in relation to solar cell/panel equivalent circuit models. Among them, the one that is most regularly used in research is the 1-Diode/2Resistor model (see Fig.2). The equation that relates the output current, $I$, to the output voltage, $V$, is the following [10]:

$$
I=I_{p v}-I_{0}\left[\exp \left(\frac{V+I R_{s}}{n a V_{T}}\right)-1\right]-\frac{V+I R_{s}}{R_{s h}}
$$

in which the first term is the photocurrent, the second one is the current through the diode, and the third term represents the current through the shunt resistor (see Fig. 2). $V_{T}$ is the thermal voltage $\left(V_{T}=\kappa T / q ; \kappa\right.$ being the Boltzmann constant, $T$ the temperature, and $q$ the electron charge), $a$ is the ideality factor of the diode, and finally $n$ is the number of seriesconnected cells within the panel.

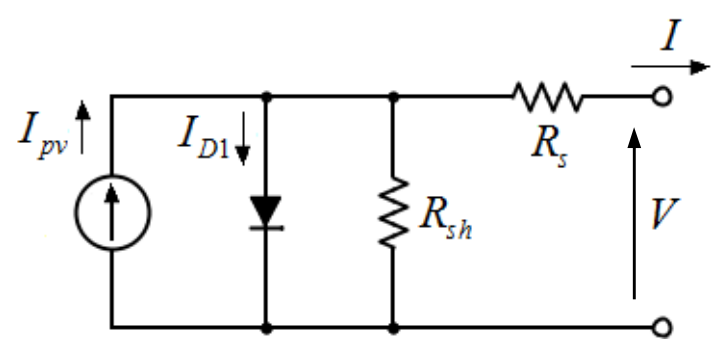

Fig. 2 Solar cell/panel 1-Diode/2-Resistor equivalent circuit.

The use of the aforementioned 1-Diode/2-Resistor equivalent circuit model by two important factors:

- On the one hand, the parameters of equation $1\left(I_{p v}, I_{0}\right.$, $a, R_{s}$, and $R_{s h}$ ) should be calculated, in relation to both the solar irradiance, $G$, on the cell/panel and its temperature, $T$, before using this model.

- On the other hand, equation (1) is an implicit mathematical expression. Therefore, for a given value of the output voltage, $V$, the calculation of the corresponding output current, $I$, is not immediate, an iteration process being necessary.

There are several methodologies to extract the parameters of the 1-Diode/2-Resistor equivalent circuit model depending on the available information [25]-[31]. If the performance curve of the photovoltaic device (that is, the $I-V$ curve, see Fig. 3) is known for certain values of irradiance and temperature, it is possible to fit equation (1) to the data. If only the characteristic points of the $I-V$ curve (short circuit current, $I_{s c}$, open circuit voltage, $V_{o c}$, and current and voltage at maximum power point, $I_{m p}$ and $V_{m p}$ ), are known, it is also possible to estimate the parameters of the model. Besides, as manufacturers normally give information on the variation of these characteristic points in relation to the irradiance and the temperature, it is possible to calculate the $I-V$ curve for any combination of the mentioned irradiance and temperature values [32]-[37].

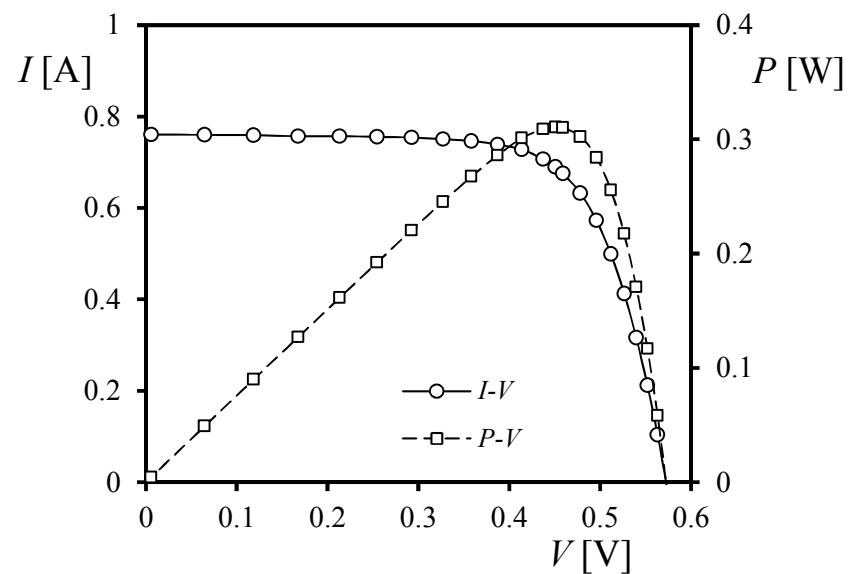

Fig. $3 I-V$ (current-voltage) and $P-V$ (power-voltage) curves of a Si solar cell.

\section{ANALYTICAL METHODOLOGIES TO EXTRACT THE PARAMETERS OF THE 1-DIODE/2-RESISTOR MODEL}

\section{A. First methodology}

If the current and voltage levels at the characteristic points $\left(I_{s c}, V_{o c}, I_{m p}\right.$ and $\left.V_{m p}\right)$ are known for certain values of the sun irradiance, $G$, and the temperature, $T$, it is possible to derive the following equations [10], [38]:

$$
\begin{gathered}
I_{p v}=\frac{R_{s h}+R_{s}}{R_{s h}} I_{s c}, \\
I_{0}=\frac{\left(R_{s h}+R_{s}\right) I_{s c}-V_{o c}}{R_{s h} \exp \left(\frac{V_{o c}}{n a V_{T}}\right)},
\end{gathered}
$$




$$
\begin{gathered}
\frac{n a V_{T} V_{m p}\left(2 I_{m p}-I_{s c}\right)}{\left(V_{m p} I_{s c}+V_{o c}\left(I_{m p}-I_{s c}\right)\right)\left(V_{m p}-I_{m p} R_{s}\right)-n a V_{T}\left(V_{m p} I_{s c}-V_{o c} I_{m p}\right)}, \\
=\exp \left(\frac{V_{m p}+I_{m p} R_{s}-V_{o c}}{n a V_{T}}\right) \\
R_{s h}=\frac{\left(V_{m p}-I_{m p} R_{s}\right)\left(V_{m p}-R_{s}\left(I_{s c}-I_{m p}\right)-n a V_{T}\right)}{\left(V_{m p}-I_{m p} R_{s}\right)\left(I_{s c}-I_{m p}\right)-n a V_{T} I_{m p}} .
\end{gathered}
$$

Once the above equations are obtained, the solution procedure is as follows:

- Estimate the ideality factor $a$. Its value is supposed to be within the bracket $[1,1.5]$ according to [37], [39].

- $\quad$ Obtain the value of $R_{s}$ from equation (4).

- $\quad$ Obtain the value of $R_{s h}$ from equation (5).

- $\quad$ Obtain the value of $I_{0}$ from equation (3).

- $\quad$ Obtain the value of $I_{p v}$ from equation (2).

Once all parameters have been extracted equation (1) needs to be solved for the required values of the solar cell/panel output voltage. As said above, this requires a certain degree of skill solving mathematical implicit equations (by iterative methods or programing the appropriate computational tools, for example). Another way to solve the explicit equation is by using the Lambert function $W_{0}$ (see Appendix) [40]:

$$
\begin{aligned}
& I=\frac{R_{s h}\left(I_{p v}+I_{0}\right)-V}{R_{s h}+R_{s}}- \\
& \frac{n a V_{T}}{R_{s}} W_{0}\left(\frac{R_{s h} R_{s} I_{0}}{n a V_{T}\left(R_{s h}+R_{s}\right)} \exp \left(\frac{R_{s h} R_{s}\left(I_{p v}+I_{0}\right)+R_{s h} V}{n a V_{T}\left(R_{s h}+R_{s}\right)}\right)\right)
\end{aligned}
$$

This methodology was successfully used by the researchers of the IDR/UPM Institute [10], [38], to fit the 1Diode/2-Resistor equivalent circuit model to the well-known experimental data from [41]. The results obtained were among the best fittings methods found in the available literature [40], [42]-[48] in terms of non-dimensional RMSE (see Table I):

$$
\xi=\frac{\mathrm{RMSE}}{I_{s c}}=\frac{1}{I_{s c}} \sqrt{\frac{1}{m} \sum_{i=1}^{m}\left(I_{\text {calc }, i}-I_{i}\right)^{2}} .
$$

where $I_{c a l, i}$ are the calculated currents and $I_{i}$ are the measured currents from the experimental $I-V$ curve.

\section{B. Second methodology}

The second methodology proposed is based on the negative branch of the Lambert function, $W_{-1}$ (see Appendix). As solving equation (4) to obtain the value of $R_{S}$ implies iteration, the following explicit equation is proposed [11]:

$$
R_{s}=A\left(W_{-1}(B \exp (C))-(D+C)\right)
$$

where:

$$
\begin{gathered}
A=\frac{n a V_{T}}{I_{m p}}, \\
B=-\frac{V_{m p}\left(2 I_{m p}-I_{s c}\right)}{V_{m p} I_{s c}+V_{o c}\left(I_{m p}-I_{s c}\right)}, \\
C=-\frac{2 V_{m p}-V_{o c}}{n a V_{T}}+\frac{V_{m p} I_{s c}-V_{o c} I_{m p}}{V_{m p} I_{s c}+V_{o c}\left(I_{m p}-I_{s c}\right)}, \\
D=\frac{V_{m p}-V_{o c}}{n a V_{T}} .
\end{gathered}
$$

The above equations were successfully applied to calculate the $I-V$ curves of a photovoltaic device for different levels of irradiance and temperature [11].

TABLE I. BENCHMARK BETWEEN THE PROPOSED METHODOLOGY (CUBAS ET AL.) AND OTHER PARAMETER EXTRATION METHODS PROPOSED BY OTHER AUTHORS. COMPARISON BASED ON THE NON-DIMENSIONAL RMSE APPLIED TO THE DATA FROM THE PWP 201 SOLAR MODULE [41]. FROM [10]

\begin{tabular}{|l|c|}
\hline Parameter extraction method & $\boldsymbol{\xi}$ \\
\hline Cubas et al. (2014) [10] & $2.85 \cdot 10^{-3}$ \\
\hline Phang et al. (1984) [42] & $3.44 \cdot 10^{-2}$ \\
\hline Easwarakhanthan et al. (1986) [41] & $5.90 \cdot 10^{-3}$ \\
\hline AlHajri et al. (2012) [43] & $3.23 \cdot 10^{-3}$ \\
\hline Boudici et al. (2007) [44] & $3.89 \cdot 10^{-3}$ \\
\hline Al Rashidi et al. (2011) [45] & $6.02 \cdot 10^{-3}$ \\
\hline Wei et al. (2011) [46] & $3.61 \cdot 10^{-3}$ \\
\hline El-Naggar et al. (2012) [47] & $2.84 \cdot 10^{-3}$ \\
\hline Peng et al. (2013) [40] & $6.16 \cdot 10^{-3}$ \\
\hline Gong et al. (2013) [48] & $2.20 \cdot 10^{-3}$ \\
\hline
\end{tabular}

\section{AN EXPLICIT METHOD AS AN ALTERNATIVE FOR THE 1- DIODE/2-RESISTOR MODEL}

Explicit methods for describing solar cells/panels' performance have been developed as an alternative to the 1Diode/2-Resistor equivalent circuit model. These methods consist of simple and explicit mathematical expressions that are more or less equivalent to equation (1), equation that defines de equivalent circuit model. As said before, these methodologies have proven to be a quite proper solution when a quick answer is required, or to be programed in some specific software environment such as ESATAN, in case of thermo-electric coupled analysis.

The following equation was proposed by IDR/UPM Institute researchers to be used instead equation (1):

$$
I=\left\{\begin{array}{ll}
I_{s c}\left(1-\left(1-\frac{I_{m p}}{I_{s c}}\right)\left(\frac{V}{V_{m p}}\right)^{\frac{I_{m p}}{I_{s c}-I_{m p}}}\right) & ; V \leq V_{m p} \\
I_{m p}\left(\frac{V_{m p}}{V}\right)\left(1-\left(\frac{V-V_{m p}}{V_{o c}-V_{m p}}\right)^{\phi}\right) & ; V \geq V_{m p}
\end{array} .\right.
$$


(oz)

$$
\cdot(x-) \mathrm{U}-\mathrm{I}-=\rho
$$

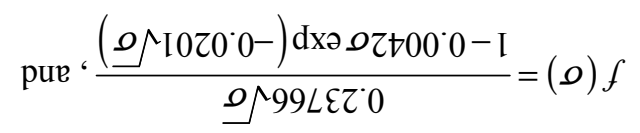

:ว.วЧМ

(oz)

$$
\begin{aligned}
& \text { ‘( }\left(\frac{(\rho) f+\mathrm{I}}{\mathrm{I}}-\mathrm{I}\right) \mathrm{I} 90 \varsigma 6 \odot-\rho-\mathrm{I}-=(x)^{\mathrm{I}-} M
\end{aligned}
$$

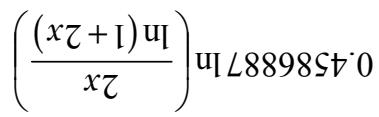

(6I)

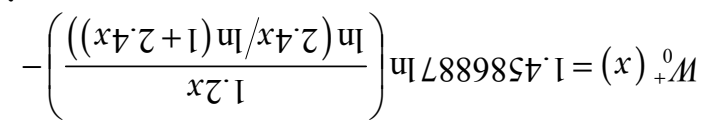

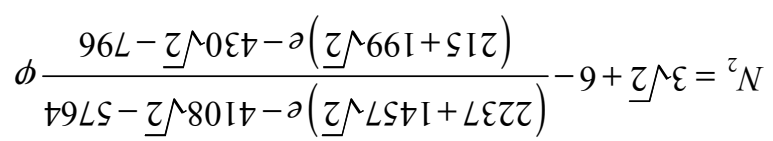

$$
\text { pue } `\left(z \jmath+{ }^{\tau} N\right)\left(\frac{z}{\mathrm{I}}-\mathrm{I}\right)={ }^{\mathrm{I}} N \cdot(x \partial+\mathrm{I}) \tau=\phi
$$

:ә.ІЧМ

(LI)

$$
\frac{\left(\phi \mathcal{S}^{2} N /\left(\phi \mathcal{\Gamma}^{\mathrm{I}} N\right)\right)+\mathrm{I}}{\phi \mathcal{I}}+\mathrm{I}-=(x){ }_{-}^{0} M
$$

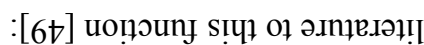

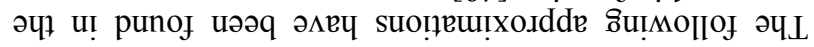

$\cdot(X) M=$

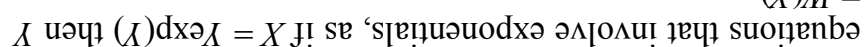

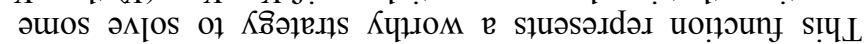
${ }^{\circ} 0 \overline{<}(x)^{0} \mathrm{M}$ Iof ' $(x)_{+}{ }^{0} \mathrm{M}$ pue ' $0>(x)^{0} \mathrm{M}$.

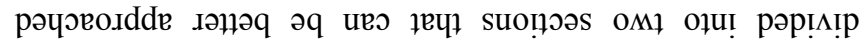

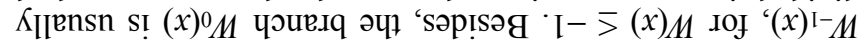

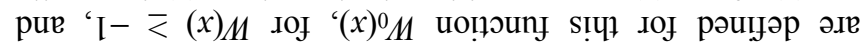

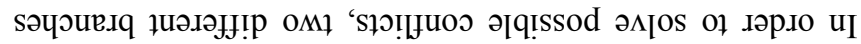

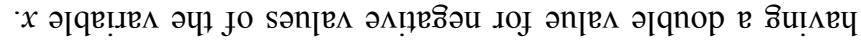

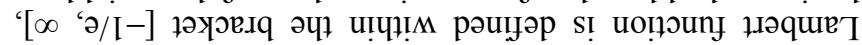

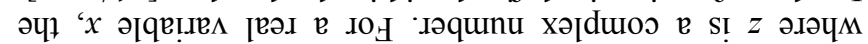

$$
\text { '((z)M)dxə(z)M=z }
$$

:uolssə.ıdxə

ภิน!ฺ

\section{XICNGddV $\cdot$ I $\Lambda$}

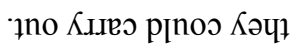

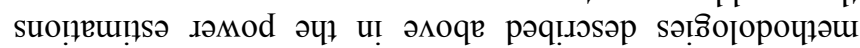

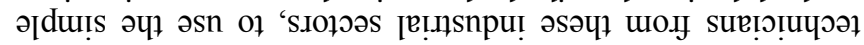

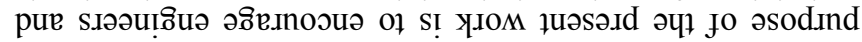

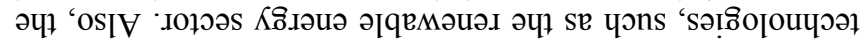

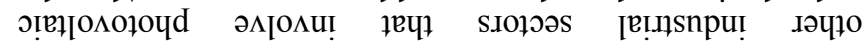

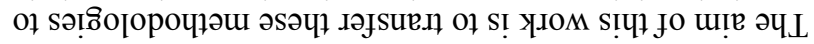

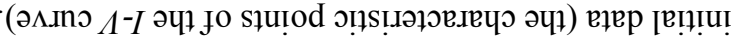

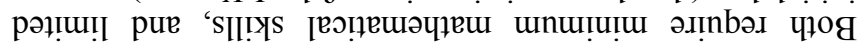

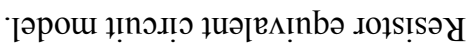

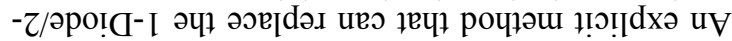

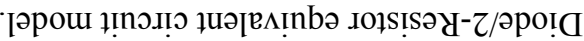

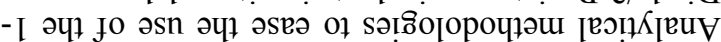

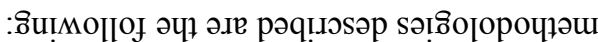

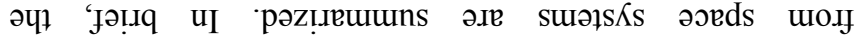

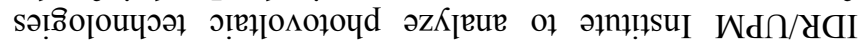

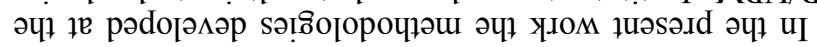

\section{SNOISRTDNOP $\wedge$}

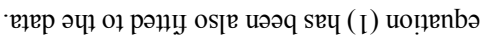

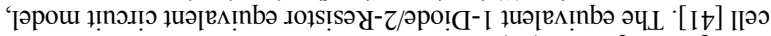
IE[OS !S әэur.

$[\Lambda]_{\Lambda}$

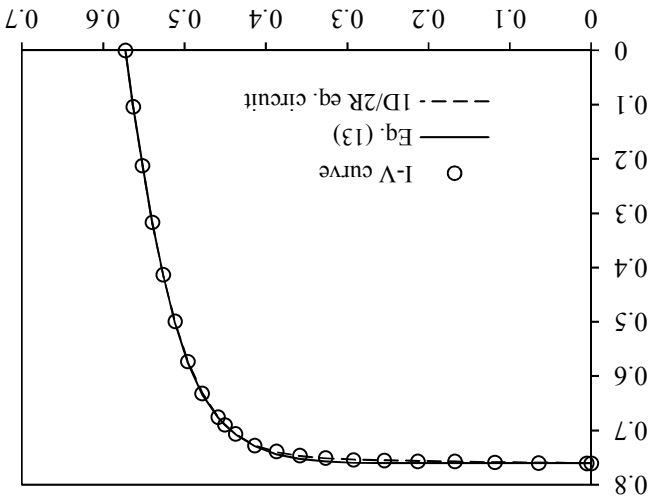

$[\mathrm{V}] \mathrm{I}$

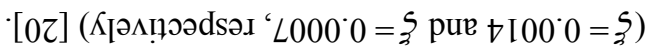

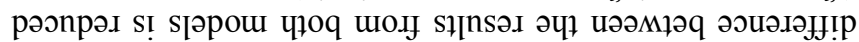

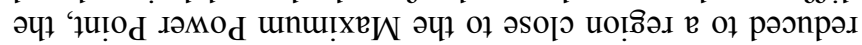

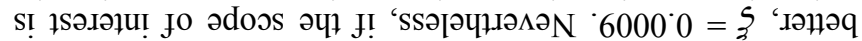

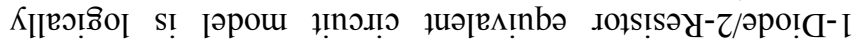

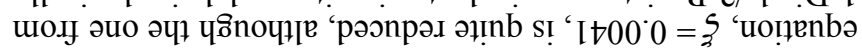

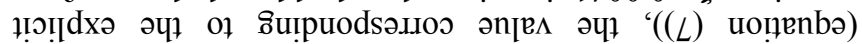

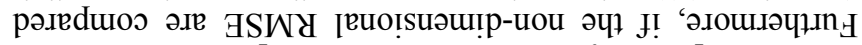

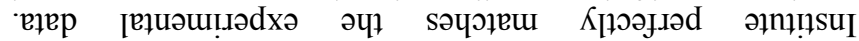

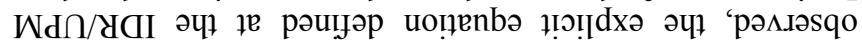

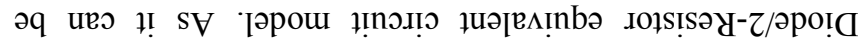

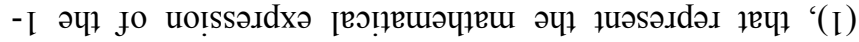

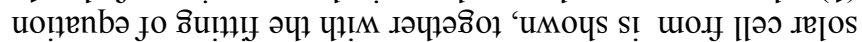

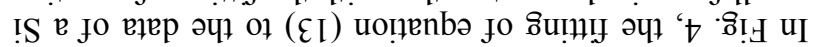

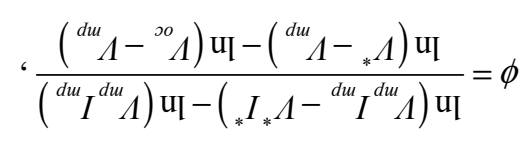

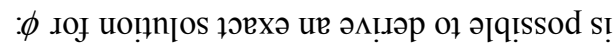

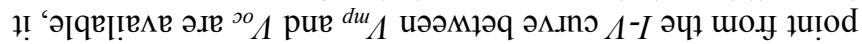

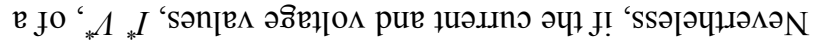

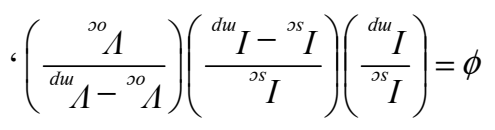

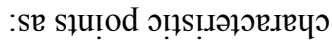

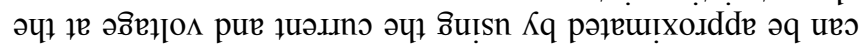

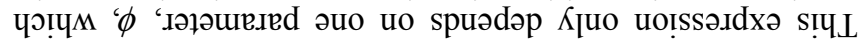




\section{ACKNOWLEDGMENT}

The Authors are indebted to the Director of the IDR/UPM Institute, Prof. Angel Sanz-Andres, for his constant support in relation to all activities related to research at this institution. Besides, Authors are grateful to the staff of the IDR/UPM Institute for their kind support in relation to the use of the facilities.

\section{REFERENCES}

[1] J. Cubas, A. Farrahi, and S. Pindado, "Magnetic Attitude Control for Satellites in Polar or Sun-Synchronous Orbits," J. Guid. Control. Dyn., vol. 38, no. 10, pp. 1947-1958, 2015.

[2] E. Rodríguez-rojo et al., "On the UPMSat-2 Attitude , Control and Determination Subsystem 's design," in 8TH European Conference for Aeronautics and Space Sciences (EUCASS), 2019, pp. 1-14.

[3] A. Gómez-San-Juan, I. Pérez-Grande, and A. Sanz-Andrés, "Uncertainty calculation for spacecraft thermal models using a generalized SEA method," Acta Astronaut., vol. 151, no. May, pp. 691-702, 2018.

[4] I. Torralbo, I. Perez-Grande, A. Sanz-Andres, and J. Piqueras, "Correlation of spacecraft thermal mathematical models to reference data," Acta Astronaut., vol. 144, no. December 2017, pp. 305-319, 2018.

[5] G. Fernández-Rico, I. Pérez-Grande, A. Sanz-Andres, I. Torralbo, and J. Woch, "Quasi-autonomous thermal model reduction for steady-state problems in space systems," Appl. Therm. Eng., vol. 105 , pp. 456-466, 2016

[6] A. García-Pérez, F. Sorribes-Palmer, G. Alonso, and A. Ravanbakhsh, "Overview and application of FEM methods for shock analysis in space instruments," Aerosp. Sci. Technol., vol. 80, pp. 572-586, 2018.

[7] A. García-Pérez, F. Sorribes-Palmer, G. Alonso, and A. Ravanbakhsh, "FEM simulation of space instruments subjected to shock tests by mechanical impact," Int. J. Impact Eng., vol. 126, no. August 2018, pp. 11-26, 2019

[8] A. García-Pérez, Á. Sanz-Andrés, G. Alonso, and M. Chimeno Manguán, "Dynamic coupling on the design of space structures," Aerosp. Sci. Technol., vol. 84, pp. 1035-1048, 2019.

[9] A. García-Pérez, M. Chimeno Manguán, Á. Sanz-Andrés, and G. Alonso, "Numerical results of modal coupling in the UPMSat-2 structure," in 8th European Conference for Aeronautics and Space Sciences (EUCASS), 2019, pp. 1-12.

[10] J. Cubas, S. Pindado, and M. Victoria, "On the analytical approach for modeling photovoltaic systems behavior," J. Power Sources, vol. 247, pp. 467-474, Feb. 2014.

[11] J. Cubas, S. Pindado, and C. de Manuel, "Explicit Expressions for Solar Panel Equivalent Circuit Parameters Based on Analytical Formulation and the Lambert W-Function," Energies, vol. 7, no. 7, pp. 4098-4115, Jun. 2014

[12] J. Cubas, S. Pindado, and A. Farrahi, "New method for analytical photovoltaic parameter extraction," in Proceedings of 2013 International Conference on Renewable Energy Research and Applications, ICRERA 2013, 2013.

[13] J. Cubas, S. Pindado, and C. De Manuel, "New Method for Analytical Photovoltaic Parameters Identification: Meeting Manufacturer's Datasheet for Different Ambient Conditions," in International Congress on Energy Efficiency and Energy Related Materials (ENEFM2013), Springer Proceedings in Physics 155, 2014, vol. 155 , pp. 161-169.

[14] J. Cubas, S. Pindado, and Á. Sanz-Andrés, "Accurate simulation of MPPT methods performance when applied to commercial photovoltaic panels," Sci. World J., vol. 2015, no. Article ID 914212, pp. 1-16, 2015.
[15] S. Pindado, J. Cubas, and F. Sorribes-Palmer, "On the Analytical Approach to Present Engineering Problems: Photovoltaic Systems Behavior, Wind Speed Sensors Performance, and High-Speed Train Pressure Wave Effects in Tunnels," Math. Probl. Eng., vol. 2015, no. Article ID 897357, pp. 1-17, 2015.

[16] S. Pindado and J. Cubas, "Simple mathematical approach to solar cell / panel behavior based on datasheet information," Renew. Energy, vol. 103, pp. 729-738, 2017.

[17] E. Roibás-Millán, A. Alonso-Moragón, A. G. Jiménez-Mateos, and S. Pindado, "Testing solar panels for small-size satellites: the UPMSAT-2 mission,” Meas. Sci. Technol., vol. 28, no. 115801, pp. $1-12,2017$.

[18] J. Cubas, S. Pindado, and F. Sorribes-Palmer, “Analytical calculation of photovoltaic systems maximum power point (MPP) based on the operation point," Appl. Sci., vol. 7, no. 9, 2017.

[19] S. Pindado, J. Cubas, E. Roibás-Millán, and F. Sorribes-Palmer "Project-based learning applied to spacecraft power systems: a longterm engineering and educational program at UPM University," CEAS Sp. J., vol. 10, no. 3, pp. 307-323, 2018.

[20] S. Pindado, J. Cubas, E. Roib, F. Bugallo-siegel, and F. S. Id, "Assessment of Explicit Models for Different Photovoltaic Technologies," Energies, vol. 11, no. 6, p. 1353, 2018.

[21] S. Pindado Carrion et al., "The UPMSat-2 Satellite: an academic project within aerospace engineering education," in Athens: ATINER'S Conference Paper Series, No: ENGEDU2017-2333, 2017, pp. 1-28.

[22] S. Pindado et al., "Master in Space Systems, an Advanced Master's Degree in Space Engineering," in Athens: ATINER'S Conference Paper Series, No: ENGEDU2016-1953, 2016, pp. 1-16.

[23] E. Roibás-Millán, F. Sorribes-Palmer, and M. Chimenno-Manguán, "The MEOW lunar project for education and science based on Concurrent Engineering approach," Acta Astronaut., vol. 148, pp. $111-120,2018$.

[24] E. Roibás-Millán et al., "Implementation of Concurrent Engineering Approach in MUSE (Master in Space Systems ) Master' s Degree in Space Engineering," in Athens: ATINER'S Conference Paper Series, No: ENGEDU2018-2537, 2018, pp. 1-19.

[25] D. T. Cotfas, P. A. Cotfas, and S. Kaplanis, "Methods to determine the dc parameters of solar cells : A critical review," Renew. Sustain. Energy Rev., vol. 28, pp. 588-596, 2013.

[26] A. K. Tossa, Y. M. Soro, Y. Azoumah, and D. Yamegueu, "A new approach to estimate the performance and energy productivity of photovoltaic modules in real operating conditions," Sol. Energy, vol. 110, pp. 543-560, 2014.

[27] A. Ortiz-conde, F. J. García-sánchez, J. Muci, and A. Sucregonzález, "A review of diode and solar cell equivalent circuit model lumped parameter extraction procedures," Facta Univ. Ser. Electron. Energ., vol. 27, no. 1, pp. 57-102, 2014

[28] D. Jena and V. V. Ramana, "Modeling of photovoltaic system for uniform and non-uniform irradiance: A critical review," Renew. Sustain. Energy Rev., vol. 52, pp. 400-417, 2015.

[29] V. J. Chin, Z. Salam, and K. Ishaque, "Cell modelling and model parameters estimation techniques for photovoltaic simulator application: A review," Appl. Energy, vol. 154, pp. 500-519, 2015.

[30] A. M. Humada, M. Hojabri, S. Mekhilef, and H. M. Hamada, "Solar cell parameters extraction based on single and double-diode models: A review," Renew. Sustain. Energy Rev., vol. 56, pp. 494-509, 2016.

[31] H. Ibrahim and N. Anani, "Evaluation of Analytical Methods for Parameter Extraction of PV modules," Energy Procedia, vol. 134, pp. 69-78, 2017.

[32] A. Bellini, S. Bifaretti, V. Iacovone, and C. Cornaro, "Simplified Model of a Photovoltaic Module," in International conference on applied electronics, 2009, pp. 47-51.

[33] M. U. Siddiqui, A. F. M. Arif, A. M. Bilton, S. Dubowsky, and M. Elshafei, "An improved electric circuit model for photovoltaic 
modules based on sensitivity analysis," Sol. Energy, vol. 90, pp. 2942, 2013.

[34] H. Ibrahim and N. Anani, "ScienceDirect Variations of PV module parameters with irradiance and temperature," Energy Procedia, vol. 134, pp. 276-285, 2017.

[35] S. Yadir et al., "Evolution of the physical parameters of photovoltaic generators as a function of temperature and irradiance: New method of prediction based on the manufacturer's datasheet," Energy Convers. Manag., vol. 203, no. November 2019, 2020.

[36] S. Lineykin, "Five-Parameter Model of Photovoltaic Cell Based on STC Data and Dimensionless," in 2012 IEEE 27th Convention of Electronical and Electronics Engineers in Israel, 2012, pp. 1-5.

[37] M. G. Villalva, J. R. Gazoli, and E. R. Filho, "Comprehensive Approach to Modeling and Simulation of Photovoltaic Arrays," IEEE Trans. Power Electron., vol. 24, no. 5, pp. 1198-1208, May 2009.

[38] J. Cubas, S. Pindado, and A. Farrahi, "New Method for Analytical Photovoltaic Parameter Extraction," in 2nd International Conference on Renewable Energy Research and Applications, ICRERA 2013, 2013, no. October, pp. 873-877.

[39] M. G. Villalva, J. R. Gazoli, and E. R. Filho, "Modeling and circuitbased simulation of photovoltaic arrays," 2009 Brazilian Power Electron. Conf., pp. 1244-1254, Sep. 2009.

[40] L. Peng, Y. Sun, Z. Meng, Y. Wang, and Y. Xu, "A new method for determining the characteristics of solar cells," J. Power Sources, vol. 227, pp. 131-136, Apr. 2013.

[41] T. Easwarakhanthan, J. Bottin, I. Bouhouch, and C. Boutrit, "Nonlinear Minimization Algorithm for Determining the Solar Cell Parameters with Microcomputers," Int. J. Sol. Energy, vol. 4, no. 1, pp. 1-12, Jan. 1986.

[42] J. C. H. Phang, D. S. H. Chan, and J. R. Phillips, "Accurate analytical method for the extraction of solar cell model parameters,"
Electron. Lett., vol. 20, no. 10, pp. 406-408, 1984.

[43] M. F. AlHajri, K. M. El-Naggar, M. R. AlRashidi, and a. K. AlOthman, "Optimal extraction of solar cell parameters using pattern search,” Renew. Energy, vol. 44, pp. 238-245, Aug. 2012.

[44] K. Bouzidi, M. Chegaar, and a. Bouhemadou, "Solar cells parameters evaluation considering the series and shunt resistance," Sol. Energy Mater. Sol. Cells, vol. 91, no. 18, pp. 1647-1651, Nov. 2007.

[45] M. R. AlRashidi, M. F. AlHajri, K. M. El-Naggar, and a. K. AlOthman, "A new estimation approach for determining the I-V characteristics of solar cells," Sol. Energy, vol. 85, no. 7, pp. 15431550, Jul. 2011.

[46] H. Wei, J. Cong, X. Lingyun, and S. Deyun, "Extracting solar cell model parameters based on chaos particle swarm algorithm," in Electric Information and Control Engineering (ICEICE), 2011 International Conference on, 2011, pp. 398-402.

[47] K. M. El-Naggar, M. R. AlRashidi, M. F. AlHajri, and a. K. AlOthman, "Simulated Annealing algorithm for photovoltaic parameters identification," Sol. Energy, vol. 86, no. 1, pp. 266-274, Jan. 2012.

[48] W. Gong and Z. Cai, "Parameter extraction of solar cell models using repaired adaptive differential evolution," Sol. Energy, vol. 94, pp. 209-220, Aug. 2013.

[49] D. A. Barry, J. Y. Parlange, L. Li, H. Prommer, C. J. Cunningham, and F. Stagnitti, "Analytical approximations for real values of the Lambert W-function,” Math. Comput. Simul., vol. 53, no. 1-2, pp. 95-103, 2000. 